\title{
BIOLOGICAL CONTROL OF GRASS GRUBS BY STARLINGS
}

\author{
R. EAST* and R. P. Pottinger \\ Lincoln College, Canterbury
}

Summary

\begin{abstract}
Starling predation of third-instar larvae gave effective biological control of grass grub in combination with irrigation, high stocking rates, and intelligent grazing management in a localized (28 ha) area of infested pastureland at Winchmore, mid-Canterbury, which had an exceptionally large autumn and winter starling population. Biological control of grass grub by starlings may only be possible in localized areas which naturally have very high numbers of starlings.
\end{abstract}

\section{INTRODUCTION}

Since DDT was banned, a single, cheap control measure has not always been available against grass grub (Costelytra zealandica White) and it is now necessary to utilize intelligently the available chemical and cultural controls. This situation has created fresh interest in the possible significance of starling (Sturnus vulgaris L.) predation on grass grubs, about which conflicting opinions have been expressed in the past (e.g., Stringer, 1965; Caithness, 1967; Trought, 1970). A more knowledgeable discussion of this topic has been made possible by recent quantitative studies (East, 1972).

\section{STARLING PREDATION ON GRASS GRUBS}

Recent studies have shown that two stages of the grass grub life-cycle are major items in starling diets in Canterbury pastureland: third-instar larvae in autumn and winter, and adults in spring (Lobb and Wood, 1971; J. D. Coleman, pers. comm.). Counts of starlings and assessment of the magnitude of starling predation on third-instar grass grubs in selected study plots (East, 1972) revealed that in most parts of Canterbury starling numbers are far too low for predation to have a significant effect. However, in an area at Winchmore with exceptionally high numbers of starlings, predation on larvae reduced grass grub populations by 40 to $60 \%$ between March and July. Predation on adults appears to have a negligible effect on grass grub populations, as most of the grass grub adults captured are either males or females which have laid most or all of their eggs (Coleman, pers. comm.), and as starlings are dispersed in their breeding sites in spring, the large flocks encountered in autumn and winter are not generally seen.

*Present address: Ruakura Agricultural Research Centre, Hamilton. 


\section{BIOLOGICAL CONTROL}

In the area of high predation at Winchmore, which was a 28 ha farmlet of border dyked, flood-irrigated pastureland on a Lismore stony silt loam, starling predation on third-instar larvae prevented the grass grub population of localized areas of infested pasture from increasing above 400 to 600 third-instar larvae $/ \mathrm{m}^{2}$ in early autumn (March). The methods and results of studies of starling predation in this area will be discussed in full elsewhere (East, 1972). Briefly, the starlings showed little interest in grass grubs until local grass grub density exceeded approximately 220 to 380 third-instar larvae $/ \mathrm{m}^{2}$. At this density the birds found it profitable to concentrate their feeding activity within localized areas of infested pasture, where they probed randomly for grass grubs. Further increases in grass grub density attracted very high numbers of starlings from a large autumn and winter roost situated in a stand of pines less than $0.8 \mathrm{~km}$ away. Predation mortality was therefore low until the density of third-instar larvae reached 220 to $380 / \mathrm{m}^{2}$, but increased steeply as grass grub density rose above this level, and prevented it from exceeding approximately $400-600 / \mathrm{m}^{2}$.

Measurement of pasture production revealed that grass grub populations of the order of 400 to 600 third-instar larvae $/ \mathrm{m}^{2}$ in March caused moderate damage to irrigated Winchmore pastures, autumn production being about $50 \%$ of that in undamaged areas within the same paddock. This reduced growth was accompanied by little death of pasture plants. Grass grub populations in excess of 800 to 900 third-instar larvae $/ \mathrm{m}^{2}$ caused severe autumn pasture damage, with much of the pasture dead and total dry matter production 10 to $20 \%$ of that in undamaged areas. Typical autumn pasture production measurements in late April within an irrigated paddock that had been hard-grazed in early February and then closed to grazing for 11 weeks are shown in Table 1. Further measurements of pasture production revealed that moderately damaged pasture recovered completely by the following spring in relation to undamaged areas, in terms of both clover and total dry matter production, with a tendency for the amount of browntop and Yorkshire fog in the sward to increase

TABLE 1: NET PRODUCTION (kg D.M./ha/day) IN THREE AREAS WITHIN A PADDOCK OF AUTUMN-SAVED IRRIGATED PASTURE AT WINCHMORE

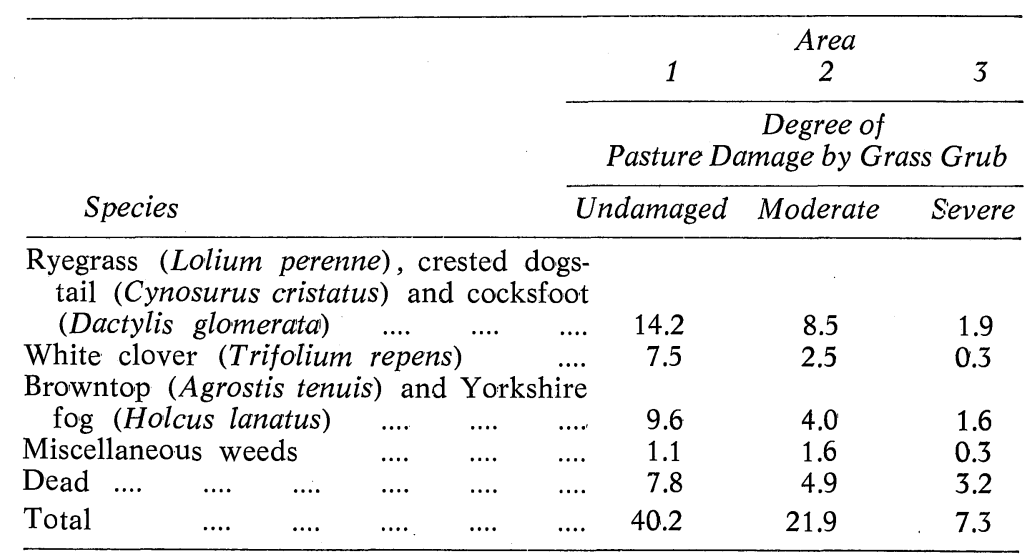


at the expense of ryegrass and crested dogstail (East, 1972). Severely damaged pasture did not recover completely by the spring. Pasture production was of the level typical of good irrigated Winchmore pasturesi.e., 10,000 to $12,000 \mathrm{~kg} \mathrm{DM} / \mathrm{ha} / \mathrm{yr}$ (Rickard and Fitzgerald, 1970), except where influenced by grass grub.

In the absence of heavy starling predation, grass grub populations of irrigated Winchmore pastures increased from moderately damaging to severely damaging levels in one year. Starlings thus gave effective biological control in the Winchmore high predation area by preventing the grass grub populations of localized areas of infested pasture from increasing above the moderately damaging level of 400 to 600 third-instar larvae $/ \mathrm{m}^{2}$. Populations of this density showed little tendency to disperse laterally, unlike the typical situation in non-irrigated pastureland (e.g. Kain and Atkinson, 1970) and the same localized areas within paddocks were infested each year. A survey showed that approximately 10 to $20 \%$ of the 28 ha high predation area was moderately damaged in autumn, the rest of the property being undamaged. Grass grub damage therefore reduced autumn pasture production by no more than about $10 \%$. Pasture utilization was unlikely to have been high enough for this loss to be significant, despite the relatively high stocking rate for the region (19.5 ewes/ha). The bulk of the ewes' winter diet was autumn-saved pasture The moderately damaged areas recovered completely by the following spring.

\section{COMPONENTS OF BIOLOGICAL CONTROL}

Biological control of grass grub at Winchmore was made possible by a combination of exceptionally high starling numbers and the following factors:

\section{Localized Grass Grub Infestation}

The 28 ha high predation area contained the only grass grub infestation within at least $1.6 \mathrm{~km}$ of the adjacent roost and therefore attracted large numbers of the birds in autumn and winter, as third-instar grass grubs are a highly favoured food of starlings. Average starling counts in grass grubinfested areas between March and July ranged from 684.6 to 1166.1 starling-hr per acre per day.

\section{IRRIGATION}

Irrigation makes third-instar larvae readily available to starlings by preventing autumn drought, which hardens the soil and forces grass grubs to remain at depths greater than $3.0 \mathrm{~cm}$. Irrigation also allows grass grub populations to reach much higher levels than in non-irrigated pastureland (Kelsey and Hoy, 1950). In the absence of irrigation, grass grub populations in Canterbury seldom increase above levels of about 300 to 400 third-instar larvae $/ \mathrm{m}^{2}$, which destroy the pasture. Since grass grubs did not become profitable to starlings in the Winchmore study area until the density of third-instar larvae exceeded approximately $220-380 / \mathrm{m}^{2}$, starling predation may be insignificant in non-irrigated areas until after severe pasture damage occurs and is therefore of no economic value. However, the profitability level observed at Winchmore may not apply in nonirrigated areas, where other factors, such as the density and availability of alternative foods, may also differ. 


\section{High Stocking Rates and Intelligent Grazing Management}

Heavy stocking at Winchmore facilitated pasture recovery by treading moderately damaged pasture, which assisted re-rooting, and by maintaining soil fertility. Treading also killed some grubs directly in severely damaged areas. Infested paddocks were closed to grazing for 4 to 12 weeks in late summer and mob-stocked from March onwards at 250 to 300 ewes/ha, attracting starlings (which avoid rank, unstocked pastures) in large numbers and allowing them to probe for grass grubs once the pasture had been grazed short.

\section{DISCUSSION}

This combination of factors has allowed successful farming at a high stocking rate for 10 to 12 years without any chemical control of grass grub, in an area severely infested with grass grub. Removal of any single factor would probably destroy the system of grass grub control. In the long term it may be necessary to introduce chemical or cultural controls, such as spring cultivation (Kain and Atkinson, 1970), to the system, since starling predation would not prevent a large part of the farmlet from eventually being occupied by moderately damaging grass grub populations which would cause a significant loss in autumn pasture production.

It may be possible to utilize starlings for biological control of grass grub in other parts of New Zealand, particularly where rainfall is equivalent in both seasonal distribution and total to that of irrigated parts of mid-Canterbury. The most important requirement is very high numbers of starlings. In the Winchmore study area this resulted from a natural concentration of starlings at a winter roost. Attempts to artificially increase a local starling population by providing attractive roosting sites are unlikely to be successful, since individual roosts may be occupied each winter for many years while apparently identical adjacent sites are ignored (Marples, 1934). In pastoral areas starlings are faced by a shortage of nesting holes, and erection of nesting boxes can increase local starling populations by at least tenfold and probably much more (Coleman, pers. comm). The breeding birds remain near their breeding sites throughout the year. Calculations based on the rate at which starlings capture grass grubs suggest that an autumn and winter starling population of the order grubs suggest that an autumn and wa 150 birds/ha, increasing to $600 /$ ha in grass grub-infested areas during wet autumn and winter weather, when most predation occurs, would be necessary for effective biological control. This is far in excess of the highest populations so far achieved by erecting resting boxes, and biological control of grass grub may only be possible in localized areas with naturally high autumn and winter starling numbers. The extent to which local starling populations can be increased by nesting box construction, the effect this has on the overall starling population of a large area as opposed to local populations, and the effects of predation on grass grub populations in the absence of the combination of factors encountered at Winchmore will only be determined by future research.

\section{CONCLUSIONS}

Starling predation of third-instar larvae gave effective biological control of grass grub in a localized area of irrigated pasture at Winchmore with a naturally very large autumn and winter starling population. Further research is necessary to show whether it is possible to increase local starling populations to the required level by provision of artificial nesting sites

\section{2}


and whether starlings can provide significant biological control of grass grub in the absence of the unusual combination of factors encountered at Winchmore.

\section{ACKNOWLEDGEMENTS}

This paper arose from research conducted by the senior author for the degree of Ph.D. Financial support was provided by a University Grants Committee Postgraduate Scholarship, a research contract with Ecology Division, DSIR, and a Nuffield Foundation Research Grant. Special thanks are due to W. R. Lobb for allowing much of the research to be conducted on his property at Winchmore, and to J. D. Coleman for helpful discussion and permission to quote from his unpublished research.

\section{REFERENCES}

Caithness, T. A., 1967. Insects and birds on two New Zealand airfields. N.Z. Ent., 4 (1): 19-23.

East, R., 1972. Starling (Sturnus vulgaris L.) predation on grass grub (Costelytra zealandica (White), Melolonthinae) populations in Canterbury, New Zealand. Ph.D. thesis, Lincoln College.

Kain, W. M.; Atkinson, D. S., 1970. A rational approach to grass grub control. Proc. 23rd N.Z. Weed \& Pest Control Conf.: 180-3.

Kelsey, J. M.; Hoy, J. M., 1950. Grass grub control. Proc. N.Z. Grassld Ass., 12: 88-94.

Lobb, W. R.; Wood, J., 1971. Insects in the food supply of starlings in mid-Canterbury. N.Z. Ent., 5 (1): 17-24.

Marples, B. J., 1934. The winter starling roosts of Great Britain 1932-33. J. Anim. Ecol., 3: 187-203.

Rickard, D. S.; Fitzgerald, P. D., 1970. The effect of soil moisture and irrigation on pasture production in Canterbury, New Zealand. Proc. $X I$ int. Grassld Congr.: 487-92.

Stringer, W. L., 1965. Starlings aplenty on Dane's Whangamata farm: no insecticides. N.Z. Jl Agric., 110 (1): 7-9.

Trought, T. E. T., 1970. Attacking grass grub on all fronts. N.Z. $l l$ Agric., 121 (3) : 22-23. 